\title{
PENAMAAN DALAM MASYARAKAT TANA TORAJA
}

(Naming Proses in Tana Toraja Society)

\author{
Resnita Dewi \\ Program Studi Pendidikan Bahasa dan Sastra Indonesia \\ Fakultas Keguruan dan Ilmu Pendidikan \\ Universitas Kristen Indonesia Toraja \\ Pos-el: resnitadewi09@gmail.com
}

\begin{abstract}
The objectives of this research is to describe (1) the reasons in naming process, (2) expectations from the naming process in Tana Toraja society. This research used qualitative method with semantic approach. Data of the research is obtained from the informants or respondents by means of interview and note technique. Selected informants or respondents must be (1) Torajanese, (2) born and/or live in Tana Toraja. The results indicated that (1) the reasons in naming process in Toraja society are (a) time of birth, (b) sequence of birth, (c) religious holidays, (d) imitating/idolizing the famous people, (e) place of birth, (f) specific occasions, $(g)$ form of acronym, (h) similarities of initial letters of the name; (2) expectations from the naming process in Tana Toraja society are (a) for goodness sake, (b) for beauty or physical health, (c) for welfare or blessing.
\end{abstract}

Keywords: naming process, society, Tana Toraja

Abstrak

Penelitian ini bertujuan mendeskripsikan (1) dasar pemberian dan (2) harapan dari nama diri pada masyarakat Tana Toraja. Penelitian ini berjenis kualitatif menggunakan pendekatan semantik. Data berupa nama diri yang diperoleh dari informan atau responden menggunakan teknik wawancara dan catat. Informan atau reponden terpilih harus (1) beretnis Toraja, (2) lahir dan atau tinggal di wilayah Tana Tana Toraja. Hasil penelitian menunjukkan bahwa (1) dasar pemberian nama dalam masyarakata Toraja adalah (a) waktu kelahiran; (b) urutan kelahiran; (c) hari-hari besar keagamaan, (d) meniru/mengidolakan orang-orang terkenal; (e) tempat kelahiran; (f) peristiwa tertentu; (g) bentuk akronim; (h) kesamaan huruf awal nama diri, dan (2) harapan dari nama yang diberikan dalam masyarakat Toraja adalah (a) untuk kebaikan atau sifat baik; (b) untuk kecantikan/ketampanan atau kesehatan fisik; (c) untuk kesejahteraan atau berkah.

Kata kunci: Penamaan, Masyarakat, Tana Toraja

\section{PENDAHULUAN}

Mempunyai nama adalah hak istimewa atau kehormatan (privelese) tiap orang. Nama itu telah dipersiapkan jauh-jauh hari sebelum anak itu lahir. Oleh karena itu, Herodotus dan kemudian juga Pliny (dalam Ullman, 2012:84) menyebutkan bahwa adalah suatu kelainan alam kepada orang-orang Atarantes (atau Altantes) dari Afrika Utara yang merupakan satu-satunya mahkluk yang tidak mempunyai nama di antara mereka.

Shakespeare yang hidup tahun 15641616 konon pernah menyatakan What is the name? (Sugiri, 2003: 56). Pendapat tersebut jika diindonesiakan menjadi apalah arti sebuah nama. Banyak yang berpandangan bahwa konon pendapat tersebut mengisyaraktan bahwa nama tidaklah memiliki arti penting. Namun tentu pula banyak tidak sepaham dengan pendapat 
tersebut. Ketidaksepahaman tersebut bisa jadi dilatarbelakangi oleh adanya pemikiran bahawa keadaan sosial bermasyarakat akan rusak bila tidak ada nama.

Potter (dalam Sugiri, 2003:55) menyatakan bahwa pada tahap awal sejarah bahasa, kata-kata pertama yang dikenal adalah nama-nama. Menurutnya, masyarakat sudah lama menyadari eratnya hubungan antara nama dan objek acuannya dan antara nama dan orang yang memilikinya (Widodo, 2010; Widodo, 2013). Masyrakat Anglo-Saxson, misalnya, selalu memegang prinsip utuh dari generasi ke generasi dalammemberikan nama-nama kepada anak-anak mereka. Begitu penting arti nama bagi pemiliknya sehingga setiap orang akan merasa jengkel apabila namanya ditulis atau diucapkan salah.

Selain "What is the name?", ada pendapat lain yang berkaitan dengan nama, yaitu "nama adalah doa". Pendapat tersebut menyatakan bahwa dalam nama seseorang terdapat doa dari yang memberikannya (Jendra, 2012; Kosasih, 2010; Suaradnyana: 2007). Misalnya dalam masyarakat Tana Toraja, seseorang diberi nama Pare (berarti padi). Pemberian nama tersebut dilatarbelakangi oleh sang anak lahir pada saat musim peparean (panen). Di balik nama Pare tersebut tersimpan harapan agar sang anak memiliki banyak rejeki.

Di sisi lain, ada seorang anak yang diberi nama Minggu, dapat disimpulkan lahir pada hari minggu, bukan hari lainnya. Di sisi lain, jika seseorang disapa dengan Lai' Minggu, maka orang tersebut berjenis kelamin laki-laki dan lahir pada hari minggu. Lahir pada hari minggu adalah latar belakang pemberian namanya. Harapan dari nama tersebut adalah agar sang anak tidak melupakan hari minggu sebagai hari beribadah bagi umat Kristiani.

Fenomena pemberian nama seperti ini, banyak ditemukan dalam masyarakat Toraja. Banyak hal yang melatarbelakangi pemberian nama tersebut. Di balik nama tersebut, juga tersimpan harapan atau dasar kepada sang empunya nama.

Berdasarkan latar belakang tersebut, maka dilakukanlah penelitian dengan judul "Pemberian Nama dalam Masyarakat Tana Toraja”. Masalah yang akan dibahas dalam penelitian ini adalah dasar atau latar belakang pemberian nama diri pada masyarakat Toraja dan harapan dari nama diri yang diberikan pada masyarakat Toraja. Berdasarkan rumusan masalah tersebut, maka tujuan dari penelitian ini adalah menjelaskan dasar atau latar belakang pemberian nama diri pada masyarakat Toraja dan harapan dari nama diri yang diberikan pada masyarakat Toraja.

\section{TEORI NAMA}

Dalam filsafat, nama diri (bahasa Latin: nomen proprium/nomina propria, bahasa Perancis: Nom propre, bahasa Inggris: Proper name atau proper noun) adalah sebuah nama yang menunjukkan hakiki suatu hal yang sedang diperbincangkan, namun tidak memberitahu lebih lanjut mengenai apa itu. Salah satu tantangan filosofi modern adalah bagaimana cara mendeskripsikan nama yang sebenarnya, dan menjelaskan artinya. 
Nama diri adalah kata yang digunakan untuk menyebut diri dan berfungsi sebagai penanda identitas seseorang. Dilihat dari segi ilmu bahasa, nama diri merupakan sebutan lingual yang dapat disebut sebagai tanda, nama diri, sebagai penanda identitas juga bisa disebut sebagai simbol dan memegang peranan penting dalam komunikasi. Nama diri sebagai penanda diri juga merupakan simbol. Contoh dalam masyarakat Indonesia nama Muhammad Alil Nursam. Kata Muhammad dalam nama tersebut menjadi penanda diri sekaligus simbol bahwa Ali Nursam adalah seorang muslim.

Plato di dalam suatu percakapan yang berjudul "cratylos" menyatakan bahwa lambang itu adalah kata di dalam suatu bahasa, sedangkan makna adalah objek yang dihayati di dunia nyata berupa rujukan, acuan, atau sesuatu yang ditunjuk oleh lambang itu. Oleh karena itu, lambang-lambang atau kata-kata itu tidak lain daripada nama atau label yang dilambangkannya, mungkin berupa benda, konsep, aktivitas, atau peristiwa (Chaer, 2002:45).

Nama adalah kata untuk menyebut atau memanggil orang (tempat, barang, dsb). Penamaan bisa dilakukan atas dasar apapun sesuai dengan keinginan yang memberi. Selain itu, dibalik nama yang diberi, sang pemberi bisa saja memiliki dasar atau harapan pribadi. Hal ini sejalan dengan pendapat Aristoteles (dalam Chaer, 2002:45) yang menyatakan bahwa pemberian nama adalah soal konvensi atau perjanjian belaka di antara sesama anggota suatu masyarakat bahasa.

\section{PENAMAAN}

Penamaan dan pendefinisian adalah dua buah proses pelambangan suatu konsep untuk mengacu kepada sesuatu referen yang berada di luar bahasa. Penamaan dalam Kamus Besar Bahasa Indonesia (KBBI) berarti proses, cara, perbuatan menamakan. Sementara oleh Kridalaksana (1993), berpendapat bahwa penamaan adalah proses pencarian lambang bahasa untuk menggambarkan objek konsep, proses, dan sebagainya; biasanya dengan memanfaatkan perbendaharaan yang ada; antara lain dengan perubahan-perubahan makna yang mungkin atau dengan penciptaan kata atau kelompok kata.

Dalam pembicaraan mengenai hakikat bahasa ada dikatakan bahwa bahasa adalah sistem lambang bunyi yang bersifat arbitrer. Maksudnya, antara suatu satuan bahasa sebagai lambang, misalnya kata dengan sesuatu benda atau hal yang dilambangkannya bersifat sewenang-wenang tidak ada hubungan "wajib" di antara keduanya. Oleh karena itu, misalnya, kita tidak dapat menjelaskan mengapa binatang berkaki dua, bersayap dan berbulu, dan biasanya dapat terbang disebut dalam bahasa Indonesia dengan nama (burung) dan buka nama lain, misal (ngurub), atau (bungur). Lagi pula andai kata ada hubungannya antara lambang dengan yang dilamangkannya itu, tentu orang Inggris tidak akan menyembutnya (bird), orang Arab menyebutnya (Thoir). Tentu mereka semua akan menyebutnya juga (burung), sama dengan orang Indonesia. 
Chaer (2002:44) menyatakan bahwa secara kontemporer, kita masih dapat menelususri sebab-sebab atau peristwaperistiwa yang melatarbelakangi terjadinya penamaan atau penyebutan terhadap sejumlah kata yang ada dalam leksikon bahasa Indonesia, yaitu (a) peniruan bunyi, misalnya, binatang sejenis reptil kecil yang melata di dinding disebut cecak karena bunyinya "cak, cak, cak,". Begitu juga dengan tokek diberi nama seperti itu karena bunyinya “tokek, tokek". Contoh lain meong nama untuk kucing, gukguk nama untuk anjing, menurut bahasa kanak-kanak adalah karena bunyinya begitu. Kata-kata yang dibentuk berdasarkan tiruan bunyi ini disebut kata peniru bunyi atau onomatope;

Penyebutan bagian, misalnya kata kepala pada kalimat 'setiap kepala menerima bantuan seribu rupiah', bukanlah dalam arti "kepala" itu saja, melainkan seluruh orangnya sebagai satu kesatu;(c) Penyebutan sifat khas, misalnya, orang yang sangat kikir lazim disebut si kikir atau si bakhil. Anak yang tidak dapat tumbuh menjadi besar, tetap saja kecil, disebut si kerdil; yang kulitnya hitam disebut si hitam; dan yang kepalanya botak disebut si botak; (d) penemu dan pembuat misalnya nama benda yang berasal dari nama orang, antara lain, mujahir atau mujair yaitu sejenis ikan laut tawar yang mulamula ditemukan dan diternakan oleh seorang yang bernama mujair di Kediri, Jawa Timur. Contoh lain nama, Volt nama satuan kekuatan aliran listri yang diturukan dari nam penciptanya yaitu Volta (1745-1787) seorang sarjana fisika dari Italia. Selanjutnya dalam dunia ilmu pengetahuan kita kenal juga nama dalil, kaidah, atau aturan yang didasarkan pada nama ahli yang mmebuatnya. Misalnya, dalil arkhimides, hukum kepler, hukum var der Tunk, dan sebagainya; (e) Tempat Asal, misalnya kata magnet berasal dari nama tempat Magnesia; kata kenari, yaitu nama sejenis burung, berasal dari nama Pulau Kenari di Afrika dan sebagainya; (f) Bahan, misalnya, karung yang dibuat dari goni yaitu sejenis serta tumbuhtumbuhan yang dalam bahasa latinnya Corchorus capsularis, disebut jyga goni atau guni. Jadi, kalau dikatakan membeli beras dua goni, maksudnya membeli beras dua karung; (g) Keserupaan, misalnya kata kaki ada frase kaki meja, kaki gunung, dan kaki kursi. Disini kata kaki mempunyai kesamaan makna dengan salah satu ciri makna dari kata kaki itu yaitu, "alat penopang berdirinya tubuh" pada frase kaki meja dan kaki kursi, dan ciri "terletak pada bagian bawah" pada frase kaki gunung; (h) Pemendekan/akronim, misalnya, abri yang berasal dari Angkatan Bersenjata Republik Indonesia, KONI yang berasal dari Komite Olahraga Nasional Indonesia, rudal berasal dari peluru kendali, lemhanas berasal dari lembaga pertahanan naisonal; (i) penamaan baru, misalnya kata turisme menjadi pariwisata.

\section{METODE}

Penelitian ini berjenis penelitian deskriptif kualitatif (Moleong, 2007; Sukidin, 2007). Data dalam penelitian ini adalah nama diri masyarakat Tana Toraja yang dikumpulkan dari informan dengan teknik catat dan teknik wawancara (Mahsun, 2007; Djajasudarma: 
2006). Informan atau reponden terpilih harus (1) beretnis Toraja, (2) lahir dan atau tinggal di wilayah Tana Toraja.Penentuan data yang dijadikan sampel dilakukan secara purposif atau sesuai dengan kebutuhan penelitian.

\section{PEMBAHASAN}

Dasar dan harapan pemberian nama dalam masyarakat Tana Toraja tersebut akan dipaparkan berikut ini.

\section{Dasar pemberian nama dalam masyarakat}

\section{Tana Toraja}

\section{a. Waktu kelahiran}

Salah satu dasar atau latar belakang pemberian nama diri dalam masyarakat Tana Toraja adalah dikaitkan dengan waktu kelahiran yakni nama bulan dan nama hari kelahiran. Waktu adalah bagian dari struktur dasar dari alam semesta, sebuah dimensi di mana peristiwa terjadi secara berurutan. Waktu merupakan suatu dimensi di mana terjadi peristiwa yang dapat dialami dari masa lalu melalui masa kini ke masa depan, dan juga ukuran durasi kejadian dan interval.

Ada dua belas bulan dalam satu tahun dan tujuh hari dalam satu minggu yang memungkinkan dijadikan sebagai dasar pemberian nama. Hal ini dapat dilihat pada nama Aprilia Lolo'. Nama diri Aprilia diberikan kepada yang empunya nama dengan dasar yang dikaitkan dengan nama waktu kelahiran. Waktu yang dimaksud adalah bulan kelahiran. Aprilia lahir di Rantepao pada tanggal 16 April1994. Jadi nama Aprilia tersebut diambil dari sebagaian kata atau morfem bebas Aprilia.
Nama lain yang berdasarkan pada bulan kelahiran adalah Febhy Yessy.Nama diri Febhydiberikan dengan dasar yang dikaitkan dengan waktu kelahiran. Waktu yang dimaksud adalah bulan kelahiran. Febhy lahir di Rantepao pada tanggal 02 Februari 1996. Jadi nama Febhy tersebut diambil dari sebagaian dari kata atau morfem bebas Februariyaitu Feb.

Penamaan lainnya yang dikaitkan dengan bulan kelahiran dapat dilihat pada namanama berikut ini. 


\begin{tabular}{|c|c|c|}
\hline $\begin{array}{l}\text { Januar } \\
\text { Janri }\end{array}$ & $\longleftarrow$ & Januari \\
\hline $\begin{array}{l}\text { Febrianti } \\
\text { Febrianto } \\
\text { Febri }\end{array}$ & & Februari \\
\hline $\begin{array}{l}\text { Aprilia } \\
\text { Aprinus } \\
\text { Aprivita } \\
\text { Apriadi }\end{array}$ & & April \\
\hline $\begin{array}{l}\text { Mei } \\
\text { Meisya } \\
\text { Meylan }\end{array}$ & & Mei \\
\hline $\begin{array}{l}\text { Juniwanti } \\
\text { Juni }\end{array}$ & & Juni \\
\hline $\begin{array}{l}\text { Julianti } \\
\text { Julian } \\
\text { Julianto } \\
\text { Juli }\end{array}$ & & Juli \\
\hline $\begin{array}{l}\text { Septian } \\
\text { Septin } \\
\text { Septrina } \\
\text { Sepriani } \\
\text { Seprianus }\end{array}$ & & September \\
\hline $\begin{array}{l}\text { Oktovio } \\
\text { Oktovianus } \\
\text { Oktaviani }\end{array}$ & & Oktober \\
\hline $\begin{array}{l}\text { Novian } \\
\text { Novianti } \\
\text { Novianto } \\
\text { Nova } \\
\text { Novri }\end{array}$ & & November \\
\hline $\begin{array}{l}\text { Desi } \\
\text { Desen } \\
\text { Destri }\end{array}$ & $\longleftarrow$ & Desember \\
\hline
\end{tabular}

Data-data di atas menunjukkan bahwa pemberian nama diri masyarakat Tana Toraja, bisa didasarkan pada waktu kelahiran, yakni yang berupa bulan kelahiran. Selain bulan kelahiran, dasar penamaan bisa juga berdasarkan hari kelahiran. Hal ini dapat dilihat pada data Sandy. Nama diri Sandy diberikan dengan dasar yang dikaitkan dengan waktu kelahiran. Waktu yang dimaksud adalah hari kelahiran. Sandy lahir di Rantepao pada tanggal 27 Agustus 1991. Sandy berasal dari kata
Sunday dalam bahasa Inggris yang berarti hari minggu. Jadi nama Sandy diberi dengan dasar hari lahir yaitu minggu.

Nama diri Sattu juga diberikan dengan dasar yang dikaitkan dengan waktu kelahiran. Waktu yang dimaksud adalah hari kelahiran. Sattu merupakan bahasa Toraja dari kata sabtu. Jadi nama diri Sattu diberi dengan dasar hari lahir yaitu sabtu. Selain itu, terdapat nama diri Minggu. Minggu merujuk pada hari setelah sabtu dan sebelum senin. Dengan, demikian 
nama diri minggu diberi dengan dasar hari lahir yaitu hari minggu. Di samping itu terdapat nama diri Duma'. NamaDuma' merupakan bahasa Tana Toraja dari jumat yang merujuk pada hari setelah kamis, sebelum sabtu. Dengan, demikian nama diri Duma' diberi dengan dasar hari lahir yaitu hari jumat.

\section{b. Urutan kelahiran}

Urutan kelahiran juga menjadi salah satu dasar dalam pemberian nama. Urutan dapat disejajarkan artinya dengan deretan; rentetan. Dengan demikian urutan kelahiran dapat diartikan sebagai deratan kelahiran. Urutan kelahiran atau rentetan kelahiran dalam hal ini adalah posisi anak dalam keluarga misalnya anak pertama, anak kedua dan seterusnya.

Hal ini dapat ditemui pada beberapa data yang ditemukan di lokasi penelitian.Nama diri Wanda Pulung diberikan dengan dasar yang dikaitkan dengan urutan kelahiran dalam keluarga. Nama Wanda mengindikasikan bahwa yang memiliki nama lahir sebagai anak pertama. Akar kata Wan pada nama Wanda tersebut berasal dari bahasa Inggris one. Kata one itu sendiri berarti kesatu atau pertama. Dengan, demikian nama diri Wanda diberi dengan dasar urutan kelahiran yakni lahir sebagai anak pertama.

Selanjutnya terdapat nama diri Dwia diberikan dengan dasar yang dikaitkan dengan urutan kelahiran dalam keluarga. Nama Dwia yakni $d w i$ mengindikasikan bahwa yang memiliki nama lahir sebagai anak kedua. Akar kata $d w i$ pada nama Dwia tersebut berasal dari bahasa Sansekerta $d w i$. Kata $d w i$ itu sendiri berarti dua. Dengan, demikian nama diri Dwiadiberi dengan dasar urutan kelahiran yakni lahir sebagai anak kedua.

Penamaan lainnya yang dikaitkan dengan urutan kelahiran dapat dilihat pada nama-nama berikut ini.

\begin{tabular}{|c|c|c|}
\hline Trisna & $\longleftarrow$ & Three (Tiga) \\
\hline Alfa & $\longleftarrow$ & Alfa (Pertama) \\
\hline Omega & $\longleftarrow$ & Omega (Terakhir) \\
\hline
\end{tabular}

c. Hari-hari besar keagamaan;

Salah satu dasar penamaan dalam masyarakat Tana Toraja adalah dikaitkan dengan hari-hari besar keagamaan. Seperti diketahui, masyarakat Tana mayoritas menganut agama Kristen, sehingga ada banyak nama diri yang berkaitan dengan hari besar agama Kristen. Selain itu, karena juga ada banyak masyarakat Tana Toraja yang beragama Islam, maka ada juga nama yang berkaitan dengan hari besar agama Islam.

Nama-nama diri yang dikaitkan dengan hari-hari besar keagamaan dapat dilihat pada dataNatalianus. Nama diri Natalianus diberikan dengan dasar yang dikaitkan dengan hari besar keagamaan. Nama Natalianus terutama akar kata nama tersebut yakni natal menunjukkan bahwa yang memiliki nama lahir pada hari natal. Hari natal itu sendiri, merupakan hari besar keagaman umat Kristen. Hari natal itu sendiri diperingati pada bulan desember. Dengan demikian nama diri Natalianusdiberi dengan dasar urutan hari besar keagamaan. Karena natal diperingati pada bulan desember, maka dapat pula diketahui bahwa yang bersangkutan lahir pada bulan Desember. 
Nama diri lain yang dikaitkan dengan hari besar keagamaan adalah Fitria. Nama Fitri pada Fitria tersebut, berdasar pada hari raya Idul Fitri. Idul Fitri merupakan suatu hari raya yang dirayakan setelah umat Islam melaksanakan ibadah puasa Ramadhan selama satu bulan penuh, dengan menahan hawa nafsu, menahan lapar dan haus dalam niat karena Allah dengan mengharap ampunan dan rahmat-Nya untuk mendapatkan ridho-Nya. Dinamakan Idul Fitri karena manusia pada hari itu laksana seorang bayi yang baru keluar dari dalam kandungan yang tidak mempunyai dosa dan salah.

Penamaan lainnya yang dikaitkan dengan hari raya besar keagamaan dapat dilihat pada nama-nama berikut ini.

\begin{tabular}{|lll|}
\hline Mery & $\longleftarrow$ & Merry Christmash \\
\hline Nataniel & $\longleftarrow$ & Natal \\
\hline Natalius & $\longleftarrow$ & Natal \\
\hline Agung & $\longleftarrow$ & Jumat Agung \\
\hline Paskalis & $\longleftarrow$ & Paskah \\
\hline
\end{tabular}

d. Meniru/mengidolakan orang-orang terkenal;

Salah satu dasar penamaan dalam masyarakat Tana Toraja adalah meniru atau mengidolakan orang-orang terkenal. Yang dimaksud dengan meniru atau mengidolakan orang-orang terkenal adalah menggunakan nama yang terdasar pada nama-nama artis atau sosoksosok tertentu yang terkenal dan diidolakan.

Penamaan yang meniru (mengidolakan) orang-orang terkenal dapat dilihat pada namanama Rossalia. Nama selanjutnya yang berdasar pada nama orang terkenal adalah Rossalia yang akrab dipanggil Rossa. Nama Rossa pada nama diri Rossalia terinspirasi dari nama penyanyi terkenal Rossa. Rossa merupakan nama panggung dari penyanyi yang bernama lengkap Sri Rossa Roslaina Handayani Sang ibu memberikan nama Rossa kepada anaknya karena saat mengandung, sang ibu sangat suka mendengar lagu-lagu yang dinyanyikan oleh Rossa. Oleh karena itu sang ibu menamai anaknya dengan Rossa.

Nama selanjutnya yang didasarkanpada nama orang terkenal adalah Welly Tanga Toding. Nama diri yang berdasarpadanama orang terkenal adalah Welly.NamaWelly merupakan nama salah seorang dokter kandungan di Tana Toraja. Saat melahirkan, ibuWelly tersebut dioperasi atau disesar oleh dr. Ricard. Oleh karena itu, pada nama diri sang anak tersebut disisipkan atau dicantumkan nama Welly.

Penamaan lainnya yang meniru (mengidolakan) orang-orang terkenal dapat dilihat pada nama-nama berikut ini.

\begin{tabular}{|lll|}
\hline Harison & $\longleftarrow$ & Harison Ford (artis) \\
\hline Anggun & $\longleftarrow$ & Anggun C Sasmi \\
\hline Judika & $\longleftarrow$ & Judika \\
\hline
\end{tabular}

e. Tempat kelahiran;

Dasar penamaan dalam masyarakat Tana Toraja adapula yang dikaitkan dengan tempat. Tempat tersebut di antaranya merupakan temtap kelahiran. Hal ini dapat dilihat pada data nama diri Tanete.Nama diri Tanete merupakan salah satu nama kampung/desa dalam masyarakat Tana Toraja yang didasar oleh tempat. 
Penamaan lainnya yang didasarkan pada tempat kelahiran dapat dilihat pada nama-nama berikut ini.

\begin{tabular}{|c|c|c|}
\hline Fatimah & - & $\begin{array}{l}\text { Lahir di rumah sakit } \\
\text { Fatimah }\end{array}$ \\
\hline Bubun & & $\begin{array}{l}\text { Lahir di sumur (bahasa } \\
\text { Toraja bubun) menuju } \\
\text { rumah sakit. }\end{array}$ \\
\hline Lalan & & $\begin{array}{l}\text { Lahir di jalan (bahasa } \\
\text { Toraja lalan) menuju } \\
\text { rumah sakit. }\end{array}$ \\
\hline
\end{tabular}

\section{f. Peristiwa tertentu;}

Dasar penamaan dalam masyarakat Tana Toraja adapula yang dikaitkan dengan peristiwa tertentu. Peristiwa tersebut misalnya dikaitkan dengan panen atau peristiwa-peristiwa tertentu. Salah satu nama yang dikaitkan dengan peristiwa tertentu adalah Pare. Nama Pare tersebut dikaitkan dengan peristiwa panen, yang mana peristiwa tersebut banyak ditemukan di masyarakat Tana Toraja, karena banyak masyarakat Tana Toraja yang bekerja sebagai petani.Kata pare dalam bahasa Toraja sama artinya dengan padi dalam bahasa Indonesia. Anak tersebut diberi nama pare karena lahir tepat pada musim peparean atau musim panen. Atas dasar inilah sehingga anak ini diberi nama pare oleh keluarganya.

Nama selanjutnya yang dikaitkan dengan peristiwa tertentu adalah Uran. Nama Uran tersebut dikaitkan dengan peristiwa alam. Kata uran dalam bahasa Toraja berarti hujan dalam bahasa Indonesia. Anak tersebut diberi nama Uran karena lahir tepat pada saat hujan deras turun.
Selain itu, terdapat pula nama Valentina. Nama Valentina tersebut dikaitkan dengan peristiwa valentine yang selalu diperingati oleh sebagian masyarakat pada tanggal 14 Pebruari. Peristiwa valentine selalu diperingati sebagai hari kasih sayang. Ada anak yang lahir pada hari tersebut yang diberi nama diri Valentina jika perempuan dan valentino jika laki-laki.

\begin{tabular}{|l|lll|}
\hline Harison & $\longleftarrow$ & $\begin{array}{l}\text { Harison } \\
\text { (artis) }\end{array}$ & Ford \\
\hline Anggun & $\longleftarrow$ & $\begin{array}{l}\text { Anggun } \\
\text { Sasmi }\end{array}$ & C \\
& & & \\
\hline Judika & $\longleftarrow$ & Judika & \\
\hline
\end{tabular}

g. Penamaan dengan bentuk akronim;

Dasar penamaan dalam masyarakat Tana Toraja ada pula yang dikaitkan dengan akronim. Penamaan tersebut dilakukan dengan mengakronimkan nama. Akronim adalah kependekan yang berupa gabungan huruf atau

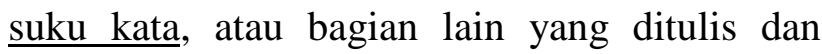
dilafalkan sebagai kata yang wajar.

Penamaan menggunakan bentuk akronim dapat dilihat pada data Elmawati Tangnga Toding. Nama Elmawati Tangnga Todingmerupakan salah satu penamaan dengan bentuk akronim. Nama yang merupakan hasil pengakroniman adalah Elma pada kata Elmawati. Bentuk Elmawati merupakan hasi penggabungan dari dua buah nama yaitu Elianus dan Mariam.Elianus adalah nama ayah dariElma, sedangkan Mariam adalah nama sang ibu. Bentuk El pada berasal dari Elianus (ayah) sedangkan bentuk ma berasal dari Mariam (ibu). 
Dengan demikian nama Elma merupakan bentuk akronim dari Elianusdan Mariam.

Penamaan lainnya yang didasarkan pada akronim dapat dilihat pada nama-nama berikut ini.

\begin{tabular}{|l|l|l|}
\hline Paregar & $\longleftarrow$ & $\begin{array}{l}\text { Paresun } \\
\text { Garonga }\end{array}$ \\
\hline Atika & $\longleftarrow$ & $\begin{array}{l}\text { Anak Tikala } \\
\text { (nama tempat) }\end{array}$ \\
\hline
\end{tabular}

\section{h. Kesamaan huruf awal nama diri}

Dasar lain dalam penamaan pada masyarakat Tana Toraja adalah didasarkan atas kesamaan huruf awal nama diri. Hal ini dapat dilihat pada adanya kesamaan huruf pertama pada anak-anak. Dasar penamaan dengan didasarkan atas kesamaan huruf awal nama diri dapat dilihat pada data Gea Trinanda. Nama Gea merupakan salah satu nama yang diberikan dengan didasarkan atas kesamaan huruf awal nama diri. Orang tua memberikan nama Gea diberikan karena kakak dari anak tersebut bernama Gian dan Gio. Pada nama tersebut terlihat bahwa terdapat kesamaan huruf pada awal nama diri yaitu $G$ pada nama diri Gian, Gio, dan $G$ pada nama diri Gea .

Penamaan lainnya yang didasarkan pada kesamaan huruf awal nama diri dapat dilihat pada nama-nama berikut ini.

\begin{tabular}{|l|l|ll|}
\hline Stevi & $\longleftarrow$ & Stella & \\
\hline Yuna & $\longleftarrow$ & Yusni, & Yudit, \\
& & Yusi, & Yoris, \\
& & Yanes & \\
\hline
\end{tabular}

\section{Harapan dari nama diri yang diberikan} pada masyarakat Tana Toraja

Harapan dapat diartikan sebagai (a) sesuatu yg (dapat) diharapkan; (b) keinginan supaya menjadi kenyataan. Nama-nama yang diberikan pada masyarakat Toraja, juga memiliki harapan. Harapan tersebut tentunya merupakan harapan orang tua atau yang memberikan nama. Harapan-harapan tersebut dipaparkan pada data-data berikut ini.

\section{a. Untuk kebaikan atau sifat baik;}

Salah satu harapan orang tua kepada anaknya yang tergambar dari nama yang diberikan adalah kebaikan atau sifat baik. Pada dasarnya, semua orang tua berharap agar anaknya memiliki sfat yang baik. Namun ada orang tua yang menunjukkan langsung harapannya itu pada nama, namun demikian adapula yang tidak. Nama untuk harapan kebaikan atau sifat baik ini dapat dilihat pada data Fajar Kameloan Liling. Salah satu nama yang menujukkan harapan orang tua untuk kebaikan atau sifat baik sang anak adalah Fajar Kameloan Liling. Kata fajar dalam Kamus Besar Bahasa Indonesia berarti "cahaya kemerah-merahan di langit sebelah timur pd waktu matahari mulai terbit. Oleh karena itu, secara umum kata fajar dalam kehidupan seharihari bermakna cahaya.Kata kedua dari nama tersebut berarti Kameloan. Kata kameloan kata berbahasa Toraja yang mengandung makna kebaikan. Adapun kata Liling yang merupakan kata ketiga dari nama tersebut merupakan marga atau nama keluarga dari garis keturunan ibu dari anak tersebut. 
Berdasarkan arti satu per satu dari katakata yang terdapat pada nama Fajar Kameloan Liling, maka dapat disimpulkan bahwa harapan orang tua kepada anaknya tersebut berdasarkan nama yang telah diberikan adalah agar sang anak dapat menjadi anak yang dapat menjadi cahaya kebaikan (kameloan) bagi dirinya sendiri secara khusus, dan terhadap orang tuanya dan sesamanya secara umum.

Harapan untuk kebaikan atau sifat baik sang anak dapat pula dilihat pada nama Pare. Kata pare dalam nama diri tersebut berasal dari bahasa Toraja dengan makna padi. Orang tua dari anak tersebut member nama Pare pada anaknya dengan harapan agar anak tersebut dapat tumbuh besar dengan berpandangan hidup seperti padi atau pare. Ada filosofi padi yakni 'semakin berisi semakin berunduk', yang juga diinginkan oleh setiap orang tua agar dilakukan oleh anaknya.

Dengan demikian dapat disimpulkan bahwa orang tua memberi nama pare pada anaknyaagar sang anak dapat hidup seperti padi, yang semakin berisi semakin berunduk. Orang tua berharap agar kelak anaknya hidup dengan menghargai sesamanya dan jauh dari kesombongan.

\section{b. Untuk kecantikan/ketampanan atau}

\section{kesehatan fisik;}

Harapan lain dari orang tua kepada anaknya yang tergambar dari nama yang diberikan adalah untuk kecantikan atau kesehatan fisik. Pada dasarnya, semua orang tua berharap agar anaknya dapat memiliki kecantikan/ketampanan atau kesehatan fisik.
Harapan orang tua tersebut dapat terlihat pada data nama Ayu Ivanka. Kata ayu dalam Kamus Besar Bahasa Indonesia berarti anggun dan menawan hati; cantik. Berdasarkan makna tersebut, maka sang ibu memberi nama Ayu kepada anaknya, agar sang anak dapat tumbuh menjadi anak perempuan yang anggung, menawan hati, dan cantik.

\section{c. Untuk kesejahteraan atau berkah}

Harapan lain dari orang tua kepada anaknya yang tergambar dari nama yang diberikan adalah untuk kesejahteraan atau berkah. Kesejahteraan atau berkah yang dimaksud adalah kehidupan yang layak dan berkecukupan.

Harapan untuk kesejahteraan atau berkah tersebut dapat dilihat salah satunya pada nama Paresun. Kata pare dalam nama diri tersebut berasal dari bahasa Toraja dengan makna padi. Padi atau pare merupakan makanan pokok masyarakat Indonesia, termasuk masyarakat Toraja. Adapun sun, sama halnya dengan pare juga berasal dari bahasa Toraja yang berarti keluar. Dengan demikian paresun berarti saat buah padi sudah mulai kuncup atau keluar.

Dalam masyarakat Indonesia, termasuk masyarakat Tana Toraja, padi merupakan hal yang mahal. Padi yang nantinya akan digiling sehingga menjadi beras lalu ditanak sehingga menjadi nasi merupakan makanan pokok seharihari. Hal ini mengakibatkan padi (beras) memiliki harga yang mahal, karena menunjukkan taraf kesejahteraan.

Masyarakat yang memiliki banyak padi menandakan bahwa mereka adalah masyarakat 
yang mampu atau sejahtera. Sebaliknya, yang tidak memiliki padi menandakan bahwa kehidupan mereka pas-pasan.

Berdasarkan hal tersebut, dapat disimpulkan bahwa orang tua member nama paresun kepada anaknya, agar anaknya dapat hidup penuh berkah dan sejahtera. Ibara padi ditanam, setiap saat akan keluar buah untuk menjadi padi yang akan dipanen, maka orang tua juga berharap agar setiap saat anaknya dapat hidup dalam keberkahan dan kesejahteraan.

\section{PENUTUP}

\section{Simpulan}

Berdasarkan pemaparan di atas, dapat disimpulkan bahwa dasar pemberian nama dalam masyarakatTana Toraja adalah (1) waktu kelahiran; (2) urutan kelahiran; (3) hari-hari besar keagamaan; (4) meniru atau mengidolakan orang-orang terkenal; (5) peristiwa tertentu; (6) bentuk akronim; (7) kesamaan huruf awal nama diri. Adapun harapan dari nama yang diberikan dalam masyarakat Tana Toraja adalah untuk (1) kebaikan atau sifat baik; kecantikan/ketampanan atau kesehatan fisik; (3) kesejahteraan atau berkah.

Selama melakukan penelitian ini, ditemukan fenomena di lapangan tentang adanya pergeseran penamaan dalan masyarakat Tana Toraja. Pergeseran tersebut anatara lain mulai banyaknya orang tua yang tidak memberikan marga pada anak mereka saat penamaan. Oleh karena itu disarankan kepada pembaca untuk melakukan penelitian legih lanjut mengenai hal tersebut.

\section{DAFTAR PUSTAKA}

Chaer, Abdul. 2002. Pengantar Semantik

Bahasa Indonesia. Jakarta: Rineka

Cipta.

Djajasudarma, Fatimah. 2006. Metode Linguistik: Ancangan Metode Penelitian dan Kajian. Bandung: Refika Aditama.

Jendra, Made Iwan Indrawan. 2012. NamaNama Diri Bermarkah: Studi Antroponimi Nama-Nama Mahasiswa Etnis Bali di Denpasar. Thesis. Linguistik. Universitas Uduyana.

Kridalaksana, Harimurti. 2008. Kamus Linguistik. Jakarta: Gramedia Pustaka Utama.

Kosasih, Dede. 2010. Kosmologi Sistem Nama Diri (antroponim) Masyarakat Sunda: dalam Konstelasi Perubahan Struktur Sosial Budaya. Makalah SeminarInternasional. Gedung Merdeka. 19-20 Februari 2010.

Mahsun. 2006. Metode Penelitian Bahasa: Tahapan Strategi, Metode, dan Tekniknya. Jakarata: Raja Grafindo.

Moleong, J. Lexy. 2011. Metodologi Penelitian Kualitatif (Edisi Revisi). Bandung: PT. Remaja Rosdakarya.

Nurhayati. 2012.From Marto to Marfelino: A Shift in Naming in Gotputuk Village. Dalam International Seminar: Language Maintenance and Shift II (Proceedings). Semarang: Master Program in Linguistic, Diponegoro University in Collaboration with Balai Bahasa Jawa Tengah.

Pateda, Mansoer. 2007. Semantik Leksikal. Jakarta: Rineka Cipta.

Rahmawati, Diah. 2013. "Pemaknaan Orang Tua terhadap Pemberian Nama Anak Studi Deskriptif Pada Masyarakat Jawa Muslim di Desa Gambiran Kecamatan Mojoagung Kabupaten Jombang”. Jurnal Universitas Airlangga. Vol. 2 - No. 2 / 2013-07. 
Suaradnyana, I Ketut. 2007. "Arti Sebuah Nama" dalam Widyaswara, Majalah Ilmiah Universitas Dwijendra, No. 08527768. Denpasar: Universitas Dwijendra

Sugiri, Eddy. 2003. Faktor dan Bentuk Pergeseran Pandangan Masyarakat JawaDalam Proses Pemberian Nama Diri: Kajian Antropologi Linguistik. Wahana Tridarma Perguruan Tinggi, Edisi 272/Juli 2000/TH/X.Surabaya : IKIP PGRI.

Ullman, Stephen (diterjemahkan oleh Sumarsono).2012. Pengantar Semantik. Pustaka Pelajar: Yogyakarta.

Widodo, Sahid Teguh. 2013. "Kontruksi Nama Orang Jawa Studi Kasus Nama- Nama Modern di Surakarta". Jurnal Humaniora. Vol. 25 No. 1 Februari 2013. Halaman 8291.

(http://jurnal.ugm.ac.id/indeks.php/jurnalhumaniora/article/view/1815).

Widodo, Sahid Teguh, dkk. 2010. "Nama Orang Jawa: Kepelbagaian Unsur dan Maknanya". International Journal of the Malay World and Civilisation. No. 28(2) (2010). Halaman 259-277. (http://journalarticle.ukm.my/1271/). 
Telaga Bahasa, Vol. 6, No. 2, Juni 2018: 433-446 